\title{
The Construction of Legitimacy in European Patent Law
}

\author{
Siva Thambisetty
}

\begin{abstract}
:
Different elements in the patent community speak of inventions and the criteria through which property rights may be granted or withheld from them in ways that are often incongruent. In large part this is due to disagreements about the functional, if not normative legitimacy, of many patentability standards. This paper examines how the European Patent Office's (EPO) practice Examination Guidelines designed to be a prosaic guide to legal standards, transforms contested inventive matter and methods into patent claims. In doing so these Guidelines manage and manipulate the legitimate expectations of the patent community. The analysis makes the broader conceptual point that patent law standards are shaped by a version of 'textualisation' that relies on linguistic and rhetorical structures to cumulatively entrench meanings, and manage the acceptance of the EPO's legal positions by those who are governed by them. The scale of textualised outcomes in patent law is a threat to coherence but also explains the EPO's ascendancy in the regulatory sphere.
\end{abstract}

Key words: Legitimacy, Patent Office, Examination Guidelines, Textualisation, Diagnostic Methods, Swiss-use Claims, Patentability 


\section{The Construction of Legitimacy in European Patent Law}

In the land of Gibberish, the man who makes sense, the man who speaks clearly, clearly speaks nonsense.

Jarod Kintz, This Book Has No Title, Kongolibrary.com 2013

Tigers eat meat. Meat is a word. Therefore tigers eat words.

Clearly there must be an error in this argument. It occurs because "meat" is being used differently in the two premises. In the second premise what is being discussed is not the substance meat, but the name of the substance. These are two different things, and the usual way of distinguishing them is to put the name in quotation marks. For a famous but more complicated example of this kind of wordplay see Lewis Carroll's "Through the Looking Glass (and What Alice Found There)", search expression, "The name of the song is called". In such a complicated situation it is easy to confuse names or descriptions and the things they refer to.

G 3/08 OJ EPO 2011, 10 [11.2.3]

Many major debates within patent law have been stagnant for decades due to competing claims about the content and purpose of patent law, kept afloat by contestable and incommensurate beliefs about the legitimacy of those claims. ${ }^{1}$ Patent

\footnotetext{
${ }^{1}$ See for instance Merges' attempt to install 'mid-level' principles consistent with a wide range of divergent commitments as an alternative to pluralistic foundational discourses. Robert P Merges, Justification of Intellectual Property (Harvard University Press 2011).
} 
law is also rife with inexplicable, even incoherent outcomes. Animals are patentable even though 'animal varieties' are an excluded category; ${ }^{2}$ there is a barely discernible difference between computer program methods (patentable) and computer programs (not patentable) ${ }^{3}$ the means of obtaining diagnostic information from a living human or animal body can be patented despite the explicit non-patentability of 'diagnostic methods'; ${ }^{4}$ and the analysis of inherent patentability relies on the search for what is 'technical' even though this phrase does not appear in Article 52(2) of the EPC 5 (which lists subject matter that are not 'inventions' as such). This paper examines the communicative structures through which legitimacy is constructed in European patent law in order to make sense of the highly incongruent ways in which different constituents speak of the rules and aims of the patent system.

\footnotetext{
${ }^{2}$ T 0315/03 OJ 2005, 246. The Biotechnology Directive (98/44/EC) and the European Patent Convention 2000 (EPC) (art 53(b)) use the term 'animal variety' which does not correspond to a recognised taxonomic category. The Agreement on Trade-Related Aspects of Intellectual Property Rights (TRIPS) excludes plants and animals (other than those produced by non-biological or microbiological processes) in art 27(3).
}

${ }^{3}$ The EPC excludes computer programs as such from patentability, but does not define them. (EPC, art 52(2) and UK Patents Act 1977, s 1(2)). See G 3/08 OJ EPO 2011, 10 at [11.2.7].

${ }^{4}$ EPC, art 53(c). EPO Examination Guidelines 4.2.1.3, n 8 below - 'Accordingly, methods for merely obtaining information (data, physical quantities) from the living human or animal body (e.g. X-ray investigations, MRI studies, and blood pressure measurements) are not excluded from patentability under Art 53(c)'.

${ }^{5}$ The 'technical' requirement cannot be traced to a single statutory provision in the EPC but surfaces in r 42(1)(a) and (c) and r 43(1) of the Implementing Regulations of the European Convention on the Grant of Patents 2014 at <https://www.epo.org/law-practice/legal-texts/html/epc/2013/e/ma2.html > accessed 16 September 2016; and is now accepted by the EPO's Patent Examination Guidelines as a further 'implicit' requirement of patentability. EPO Patent Examination Guidelines, pt G. 
Rather than focus on outcomes (what is patentable?) my aim here is to unpack the process (how does it become patentable or not patentable?) of specifying patentability through the dynamic of textualisation. I argue that legitimacy ${ }^{6}$ at the level of examining practices in patent offices is socially constructed, its claims managed through unusual textual arrangements that frame resolutions of disputed or uncertain legal positions with a view to gaining credibility amongst the constituents it addresses. ${ }^{7}$ Given uncertain or contested positions, how you say it can become even more significant than what you say; and cumulatively these textual arrangements can supplant conventional meanings. Textualisation is not in itself a normative phenomenon but it can deepen partisan outcomes, and facilitate agency in the patent system.

I build my argument primarily on patent examining guidelines, and the two examples I analyse here relate to the European Patent Office (EPO). ${ }^{8}$ Explanatory

\footnotetext{
${ }^{6} \mathrm{I}$ rely on ideas of organisational legitimacy and those emerging from regulatory parlance. Mark C Suchman, 'Managing Legitimacy: Strategic and Institutional Approaches' Academy of Management Review 20, 571 (1995); Steven Bernstein and Benjamin Cashore, 'Can Non State Global Governance be Legitimate? An Analytical Framework’ Regulation and Governance (2007) 1, 347; J Black, 'Legitimacy and Competition for Regulatory Share' LSE Law, Society and Economy Working Paper Series 14/2009; Julia Black, 'Constructing and Contesting Legitimacy and Accountability in Polycentric Regulatory Regimes' Regulation and Governance (2008) 2, 137-164.

${ }^{7}$ Black, 'Constructing and Contesting Legitimacy' ibid.

${ }^{8}$ The EPO is the implementing body under the EPC and the Examination Guidelines under the EPC are available at <http://www.epo.org/law-practice/legal-texts/guidelines.html_. The UK Intellectual Property Office (UKIPO) publishes guidelines called the Manual of Patent Practice implementing the Patents Act 1977 which loosely mirror the EPC Guidelines. These are provided on the UKIPO website under 'Guidance' at <http://www.ipo.gov.uk/pro-types/pro-patent/p-law/p-manual/p-manualpractice/p-manual-practice-pat1977.htm $\geq$. (URLs accessed 16 September 2016.)
} 
insights about the legal status of these guidelines and the component elements of textualisation can, despite other institutional differences, be generalized to other major patent offices like the United States Patent and Trademark Office (USPTO). In part 1 I examine the status of patent examination guidelines which are not law as such but function nonetheless as a source of legitimate expectations. From an institutional and behavioural perspective this dual status allows textualisation to take root and flourish.

In part 2 I discuss textualisation as an institutionally embedded phenomenon ${ }^{9}$ that comes into play when broad categories in the statute or vaguely worded legal decisions have to be operationalized and turned into 'guidance' for the patent community. While textualisation can materialize in other areas of the law, what makes it particularly prolific here is 'technolaw' - a legal dialect peculiar to the interface of law and technology, much like technoscience in Latour's science in action. ${ }^{10}$ Technolegal language is highly stylized, complex, compacted and detached from normative underpinnings, which cumulatively set legal positions that are hard to scrutinize or authoritatively deviate from.

In part 3 I analyse two cases of textualisation - that of claim language around diagnostic methods and Swiss-type use claims in EPO practice ${ }^{11}$ to isolate constituent

\footnotetext{
${ }^{9}$ Institutional approaches to patent law are uncommon but see Peter Drahos, The Global Governance of Knowledge: Patent Offices and Their Clients (Cambridge University Press 2010); Shobita Parthasarathy, 'Breaking the Expertise Barrier: Understanding Activist Challenges to Science and Technology Policy Domains' Science and Public Policy (2010) 37 Science and Public Policy 5, 355367; Alain Pottage and Brad Sherman's Figures of Invention: A History of Modern Patent Law (Oxford University Press 2011).

${ }^{10}$ Bruno Latour, Science in Action (Harvard University Press 1987).

${ }^{11}$ EPO Examination Guidelines pt G.
} 
elements of textualisation such as stratified language, the use of positive and negative modalities, the creation of black boxes and the ahistorical presentation of previously disputed legal positions.

In part 4, I explore how textualisation allows the EPO to create, repair and maintain it's own legitimacy in the face of competing values and multiple national and transnational units working inter-relatedly to regulate innovation.

\section{Patent Examination Guidelines}

The status, formulation and function of the text in the Patent Examination Guidelines at the EPO (hereinafter the Examination Guidelines) is central to my argument. There are primarily two reasons why Examination Guidelines allow for the strongest version of my argument on textualisation. First there is a gap between the legal status and actual function of these texts within different parts of the patent community. Secondly many provisions of the EPC simply do not possess the operative details needed to guide patent applicants, which makes the Examination Guidelines a critical source of legitimate expectations.

The power to draft Examination Guidelines is part of the operative power given to the European Patent Office (EPO), rather than the administrative council of the European Patent Organisation (EPOrg) which has limited legislative powers related to the text of the European Patent Convention. ${ }^{12}$ The EPO produces Examination Guidelines under the umbrella of Article 10(2)(a) of the EPC - the power to 'take all necessary steps to ensure the functioning of the European Patent Office, including the adoption of internal administrative instructions and information to the public.' The guidelines are clearly not expressly required by the primary

\footnotetext{
${ }^{12}$ See <https://www.epo.org/about-us/organisation.html $\geq$ accessed 16 September 2016.
} 
legislation, and while addressed to EPO staff are also intended to inform applicants as to how the EPO might be expected to apply the law and act procedurally. ${ }^{13}$ They are not however, a primary source of law per $s e^{14}$ and do not set up a system of rules $a$ priori. While they are summative of a particular jurisdiction's patent standards they are also an intermediary legal product of statutory interpretation and legal reasoning, as formulated by patent offices.

In this paper, I deal mostly with decisions or positions reached by EPO Boards of Appeal in areas that are not catered for in detail in the EPC. There are also significant instances of conflicting Boards of Appeal decisions. ${ }^{15}$ Examination

\footnotetext{
${ }^{13}$ EPO Examination Guidelines General pt - 4. 'There may be cases in which the public has a legitimate expectation that the first instance will not deviate from the established case law. This might be accepted if this case law had become part of a consistent practice of the first instance, in particular if this has been made known to the public by published Guidelines, Legal Advice or Notices from the EPO.' J 27/94, 27 February 1995, OJ 1995, 831 at [5].

14 'It should be noted also that the Guidelines do not constitute legal provisions... Nevertheless, as a general rule, parties can expect the EPO to act in accordance with the Guidelines until such time as they - or the relevant legal provisions - are amended.' EPO Guidelines General pt - 4. UKIPO Manual of Patent Practice notes '[S]tatements made in the Manual are not in themselves an authority for any action by the Intellectual Property Office and should not be used as a set of legal requirements'. n 8 above.
}

${ }^{15}$ Rules of Procedure of the Boards of Appeal (RPBA) 2003, art 20, EPO at <http://www.epo.org/lawpractice/legal-texts/html/caselaw/2013/e/clr_rpba.htm $\geq$ accessed 16 September 2016. There are 28 Technical Boards of Appeal (TBA) that together with the Legal Board of Appeal examine appeals from the receiving section, examining division and the opposition division <https://www.epo.org/aboutus/boards-of-appeal.html $\geq$ accessed 16 September 2016. 
Guidelines are not formulated by Boards of Appeal, ${ }^{16}$ are not binding on them ${ }^{17}$ and cannot override an article or rule of the $\mathrm{EPC}^{18}$ but it 'does not mean that the boards do not apply them or quote then as a source of inspiration. ${ }^{, 19}$

Where Boards deviate from Examination Guidelines they are not obliged to state the grounds for doing so but only to in general terms, "state the grounds for its action if it considered that [its] decision [would] be more readily understood in light of such grounds. ${ }^{20}$ Even a divergence between established case $1 \mathrm{law}^{21}$ and Examination Guidelines is not sufficient basis for a referral to an Enlarged Board of Appeal. $^{22}$ There is no notion of precedent as such when it comes to Boards of Appeal decisions and there are many ways of graduating the authoritativeness of a prior decision $^{23}$ - all of which add to the uncertainty that are resolved or presented as resolved in the Examination Guidelines.

16 ، ...the formulation of the Guidelines for Examination is not the responsibility of the Boards of Appeal'. T 1741/08 [3.3].

${ }^{17} \mathrm{~T}$ 156/05 (17 October 2005). While Article 112(3) of the EPC provides that a decision of the Enlarged Board of Appeal is binding on Boards of Appeal in relation to an appeal in question, there is also the possibility of deviating from an Enlarged Board's decision with a fresh reference to the Enlarged Board. RPBA 2003, art 21.

18 T $1356 / 05$.

${ }^{19}$ See Rules common to all proceedings before the EPO, EPO Case Law of the Boards of Appeal, <http://www.epo.org/law-practice/legal-texts/html/caselaw/2013/e/clr_iii_s_1.htm > accessed 16 September 2016.

${ }^{20}$ RPBA 2003, art 15(2).

21 'Case law' as published by the EPO.

${ }^{22}$ RPBA 2003, art 15(2).

${ }^{23} \mathrm{By}$ the degree of distribution indicated on the decision; or by distinguishing a previous decision based on a material fact. See Darren Smyth, 'What is precedent and does the EPO have it?' (15 July 
In contrast the Examination Guidelines are in fact binding in principle, on examining departments of first instance because they are general instructions that cover 'normal circumstances' to be departed from only in exceptional circumstances by examining staff. ${ }^{24}$ Consequently and notwithstanding the lack of formal oversight or scrutiny, such practices are 'normalized' when they are in accordance with the Examination Guidelines. It is this instrumental aspect of the guidelines that I am mostly concerned with.

It is still possible for an examining division to deviate from the Examination Guidelines. To do so would not be a procedural violation unless it also constitutes a violation of a rule or principle of procedure governed by an article of the EPC or one of the Implementing Regulations. ${ }^{25}$ While clearly there is no guarantee that Examination Guidelines comply with Implementing Regulations or rules or procedure governed by one of the articles of the EPC, the extensive (794 pages of single spaced text), ${ }^{26}$ detailed and highly referenced nature of the Examination Guidelines covering both procedural and substantive aspects, and its presentation in the format of conventional legal text all adds to the expectation that they will guide examining division decisions, except when they do not.

It is worth saying here that de facto, expertise based on the Examination Guidelines is a requirement to become eligible to register as a patent attorney. The final examination guidance from the UK Chartered Institute of Patent Attorneys

2014) <http://ipkitten.blogspot.co.uk/2014/07/what-is-precedent-and-does-epo-have-it.html $\geq$ accessed 16 September 2016.

${ }^{24}$ EPO Examining Guidelines General pt - 4. Also see T 162/82 OJ 1987, 33 and T 42/84 OJ 1988, 251.

${ }^{25}$ T 1388/10. See n 5 above.

${ }^{26} \mathrm{n} 8$ above (November 2015 edition). 
presses candidates to 'be familiar with the principles of drafting descriptions, claims and abstracts for UK, European and International Patent Applications as indicated in the Patent Office Manual of Patent Practice. ${ }^{27}$ The requirement strongly suggests that the guidelines set up professional benchmarks on how things ought to be done.

Secondly, Examination Guidelines are well suited to textualised outcomes because of the lack of detail in the EPC, which together with the possibility of divergence amongst Boards of Appeal decisions makes the Guidelines a critical and active source of legitimate expectations. Unlike a Board of Appeal, an Enlarged Board of Appeal's jurisdiction ${ }^{28}$ is not limited to the facts of pending appeals and extends to points of law referred to it under Article 112(1) (b) - an authority that is seen as necessary due to 'numerous undefined legal terms', the challenges of 'new technologies' and the 'fact specific nature of patent law' ${ }^{29}$ This is a process that can lead to changes or clarifications in the Examination Guidelines. In this uncertain landscape, the Examination Guidelines in effect set up behavioural defaults ${ }^{30}$ when it

\footnotetext{
${ }^{27}$ See FD2 Guidance 2015, CIPA at <http://www.cipa.org.uk/patent-examinationboard/support/examination-guidance $\geq$ accessed 16 September 2016.

${ }^{28}$ Art 112 of the EPC. Art 112(1)(b) in particular states, 'In order to ensure uniform application of the law, or if a point of law of fundamental importance arises:...the President of the European Patent Office may refer a point of law to the Enlarged Board of Appeal where two Boards of Appeal have given different decisions on that question.'

${ }^{29} \mathrm{G} 3 / 08$ (n 3 above) at [7.2.6]-[7.3.8].

30 'Defaults are the options that are pre-selected if an individual does not make an active choice.

Defaults exert influence as individuals regularly accept whatever the default setting is, even if it has significant consequences.' Paul Dolan et al., Mindspace: Influencing Behaviour Through Public Policy Cabinet Office (Institute for Government, 2009) 23 at <http://www.instituteforgovernment.org.uk/sites/default/files/publications/MINDSPACE.pdf $\geq$
} 
comes to how patent applicants respond to substantive and procedural requirements of the law.

Boards of Appeal are, in fact, aware of the way in which Examination Guidelines can create default settings. In T 1607/08 the Board termed the Examination Guidelines published by the EPO as 'one of the sources of legitimate expectations $^{31}$ along with specific communications or actions within the framework of particular proceedings. Legitimate expectations can also properly arise from the actual general conduct or established practice of organs of the EPO, and changes in these practices should be officially notified to avoid misleading the parties. ${ }^{32}$

The shifting ground that props these Examination Guidelines is part of the infrastructure that makes textualisation critical - on the one hand the text legitimately guides commercial prospects and behaviour in the patent community but if you try to pin it down and situate it within the body of patent law, it can seemingly evaporate. The result is text that is not subject to oversight, and yet influences every patent applicant who seeks a patent on her invention. It is also not out of the question that

accessed 16 September 2016. Also see Dan Ariely, Predictably Irrational: The Hidden Forces That Shape Our Decisions (HarperCollins 2008).

31 'The principle of the protection of legitimate expectations, also referred to as the principle of good faith, generally recognised among the Contracting States, is also a well established principle in proceedings pursuant to the EPC. Its application to procedures before the EPO implies that measures taken by the EPO should not violate the reasonable expectations of the users of the European patent system.' T 1607/08 [2].

${ }^{32}$ T 905/90 OJ 1994, 306, Corr. 556. 
cumulatively, unscrutinized guidance can create legitimate expectations that can percolate up to legislative organs or down to national judicial bodies. ${ }^{33}$

With the above qualifications on legal status, exemplars of claims within Examination Guidelines direct patent applicants to describe their inventions in legally appropriate terms ${ }^{34}$ and frequently, patent applicants are expected to claim particular kinds of inventions in specific ways. Claim formulations or claim types are borne out of convention ${ }^{35}$ or expediency and can also stem from or be modified by decisions of the Boards of Appeal. The prosaic view of claim types is that these are but a necessary aspect of registration requirements in patent law. In practice however the

\footnotetext{
${ }^{33}$ National courts deal with infringement actions and can invalidate patents granted by the EPO. National patent offices in contracting states are expected to harmonize practice with the $\mathrm{EPO}$, but follow national courts in case of divergences, creating in turn pressure on appellate authorities to ease the way of patent offices by in effect legitimising EPO practice. This is one explanation for the 15 principles in EPO case law approved by the UK Supreme Court in Human Genome Sciences v Eli Lilly and Co [2011] UKSC 51, [38]-[41], [2011] WLR (D) 312.
}

34 'Terms in a claim broadly fit three categories - structure, function and advantage and the choice of term should reflect the inventive contribution made'. See Ian Karet, 'Construction of Patents' in Ashley Roughton et al, The Modern Law of Patents (Lexis Nexis Butterworth 2005). While it is now accepted that an invention is defined by claims, it was not always so. In Germany until the EPC and art 69 and its protocols claims only had a minor role in determining scope of protection; and until recently in the UK it was possible to infringe by taking the 'pith and marrow' of the invention although there had been no infringement of the claims as such. See 'The effect of different claim formulations' in ch VI, EPO Guidelines, $\mathrm{n} 8$ above.

${ }^{35}$ An example of a claim type is the two-part claim, seen in $r$ 43(1)(a) of the EPC Examination Guidelines F IV 2.2, that must be used 'wherever appropriate'. The first part of a Jepson claim details prior art, the second features what the invention adds to the prior art. This form can be double-edged for patent applicants - they are easy to write but are tantamount to an admission of closest prior art, which could work against patentability of the claim. 
structure and terminology of claim types can have significant impact on the scope of protection particularly where the EPC is silent on the detail of how inventions are to be marked out from what already exists in the prior art, or from what is not inherently patentable by law.

In order to know precisely what is patentable you need to know how to write the corresponding claim(s); and even more importantly how those claims will be read by notional addressees in law. ${ }^{36}$ There is a great deal of indeterminacy in this process, not all of which can be linked simply to the difficulty in mapping words to things. There is also a failure to reflect on the cognitive burden set by trying to assign meanings to textual elements that can extend from the very narrow to the very abstract as recognised by Burk and Lemley. ${ }^{37}$

The substantive requirement of 'technical' for instance, has had a significant impact on how inventions that implement computer programs and business methods are claimed. The struggle to avoid characterising all computer-implemented inventions as 'computer programs' has led to the acceptance of a number of descriptions short of this term in claim language. While computer programs and business methods are exceptions to inventions in the EPC, a 'computer implemented method' or 'computer implemented business methods' are not ${ }^{38}$ and are examined distinct from the computer program or business method corresponding to that method. Both 'computer program products' and 'computer program methods' are also valid

\footnotetext{
${ }^{36}$ John M Golden, 'Construing Patent Claims According to Their "Interpretive Community": A call for an Attorney plus Artisan Perspective' 21 Harv. J. Law \& Tech. 321, 322-29, 368-85 (2008).

${ }^{37}$ Dan Burk and Mark Lemley, 'Quantum Patent Mechanics' Lewis \& Clark Law Review, Vol. 9, p. 29, 2005.

${ }^{38} \mathrm{G} 3 / 08$ (n 3 above).
} 
claims for computer-implemented inventions ${ }^{39}$ that fall short of being computer programs 'as such'. ${ }^{40}$

To give a related example, while the US statute is silent as to what does not constitute patentable subject matter, judicial precedent explore a small number of prohibited categories including product of nature, abstract ideas and laws of nature. According to the US Supreme Court in Alice Corp v CLS Bank International ${ }^{41}$ if 'the claimed invention involves a prohibited category then under the second prong of the test, analysis shifts to whether the inventor has added 'something more' which might constitute an 'inventive concept' beyond an abstract idea, law of nature or (presumably) a product of nature.' The decision did not give further content to this idea of 'something more' 42 - a task that is left to the USPTO.

Merely knowing the law (which stipulates that laws of nature, natural phenomenon or abstract ideas are not patentable) is inadequate; in order to know what is patentable you need to know how to write an acceptable claim. This process of transposing the meaning of the judicially created exclusions into claim language within interim examination guidelines can leave generous room for interpretation. ${ }^{43}$

\footnotetext{
${ }^{39}$ ibid at [11.2.7].

${ }^{40}$ See T 1173/97 OJ 1999, 609 and T 424/03. For a fuller discussion see Sivaramjani Thambisetty,
} 'Alice and 'Something More': The Drift Towards European Patent Jurisprudence (Peer Commentary)' in Journal of Law and the Biosciences (forthcoming).

41 134 S.Ct 2347.

${ }^{42}$ Dan L Burk, 'Dolly and Alice' Journal of Law and the Biosciences, 2 (3) 606-626.

43 'At some level all inventions embody, use, reflect, rest upon or apply a law of nature, natural phenomenon, or abstract idea ([added $]$ all of which are judicial exceptions to patentability under US law]). To properly interpret the claim, it is important to understand what the applicant has invented and is seeking to patent.' Federal Register Vol 79, No 241 Dec 16 2014, 74622. 
Here is a more colourful way of characterising the significance of the 'guidance-making' authority of the patent office, in the words of Merges following Alice:

Reading the opinion reminds me of a famous passage in The Hitchhiker's Guide to the Galaxy. Acolytes wait at the feet of a giant supercomputer, which 7.5 million years before had been asked "What is the meaning of life?" Finally, after eons of waiting, the computer spoke. Its answer was: “42.” The acolytes went forth, armed with this non-answer. And life went on. So it is with us, in the patent field. We have met our " 42 ," and its name is Alice. Now life must go on. ${ }^{44}$

Following the decision it is left to the USPTO to convey to patent applicants and others in the patent community the answer to the question 'is software patentable' by interpreting the meaning of 42 . This work of positioning substantive interpretation into operating guidelines, based on decisions either by courts or patent offices themselves is an important element of the implementing power that patent offices have. Although this power is not meant to be legislative, equally, when decisional precedents are complex or broadly worded this power can become critical.

\footnotetext{
${ }^{44}$ Rob Merges, 'Go ask Alice - what can you patent after Alice v. CLS Bank?' <http://www.scotusblog.com/2014/06/symposium-go-ask-alice-what-can-you-patent-after-alice-v-clsbank/ $\geq$ accessed 16 May 2015. The latest Interim Examination Guidelines (USPTO) is driven by the need to guide patent applicants following three recent Supreme Court decisions -Alice Corporation v CLS Bank 134 S.Ct 2347, AMP v Myriad Generics Inc 133 S Ct, 2107 and Mayo Collaborative Serv v Prometheus Labs Inc $132 \mathrm{~S} \mathrm{Ct} \mathrm{1289.} \mathrm{'It} \mathrm{is} \mathrm{recognised} \mathrm{that} \mathrm{under} \mathrm{the} \mathrm{controlling} \mathrm{legal} \mathrm{precedent} \mathrm{there}$ may be variations in the precise contours of the analysis for subject matter eligibility that will still achieve the same end result. The analysis set forth herein promotes examination efficiency and consistency across all technologies' (Federal Register Vol 79, No 241 December 16 2014, 74620).
} 
The dialectal of patent law has always held weighty implications because of the need to describe that which has been invented - a process that cannot always guarantee precision or even accuracy. ${ }^{45}$ While words may adequately describe structure, function or advantage of the invention on their own, some inventions merge these attributes generating uncertainty in what exactly has been invented or where the inventive contribution lies. In the case of gene patents for instance the structural description of genes that is their molecular avatar, does not always reflect the functional or informational nature of such inventions leading to considerable uncertainty in specifying boundaries of what is protectable. ${ }^{46}$ In other cases, emerging technologies can generate uncertainty in fixing the meaning of rapidly evolving terms. The sociotechnical process of invention so evocatively depicted in Myers' work also urges us to take note of myriad influences - legal advice, commercial sense, experimental evidence. In this sense texts, particularly claim language, are not simply texts, rather they are intermediaries that give access to a much wider view of agency. 47

Law is always mediated through legal form and language, and its practice necessarily interpretative. Scholars such as Constable ${ }^{48}$ have analysed how language,

\footnotetext{
${ }^{45}$ Greg Myers, 'From Discovery to Invention: The writing and Rewriting of Two Patents' Social Studies of Science February 1995 vol. 25 no. 1 57-105.

${ }^{46}$ Rebecca S Eisenberg, 'Patents on DNA Sequences: Molecules and Information.' in Niva ElkinKoren and Neil Weinstock Netanel (eds), The Commodification of Information (Kluwer Law International 2002) and Sivaramjani Thambisetty, 'Learning Needs in the Patent System and Emerging Technologies: A Focus on Synthetic Biology' (2014 Intellectual Property Quarterly (1).

${ }^{47}$ See n 45 above

${ }^{48}$ Marianne Constable, Just Silences: The Limits and Possibilities of Modern Law (Princeton University Press 2007).
} 
speech and memory ${ }^{49}$ are all implicated in law as a sociological phenomenon. Placing the form of the law within the specific communities it addresses can help understand these processes better. For instance, Golden's historical analysis of the 'artisan' of ordinary skill, the notional addressee of patents, shows how focus on a narrow interpretive community skews the understanding of legal concepts. ${ }^{50}$ Pottage and Sherman draw out the conceptual difference between the intangible invention and the text of the patent that is 'generated and sustained by real world acts of representation, interpretation and argumentation'. ${ }^{51}$ This intermediated text becomes a conduit between the social world and third parties and over time generates an epistemic community. Burk and Reyman also observe and argue that the patent system is largely text-based and that patents are fundamentally rhetorical ${ }^{52}$ In doing so they ask

49 'The Objective facts about the past are less important than the existence of widely shared beliefs about the past. Law is involved in the creation and preservation of this common past.' W T Murphy The Oldest Social Science? Configurations of Law and Modernity (Clarendon Press 1997), 90. ${ }^{50}$ Golden, n 37 above.

${ }^{51}$ Pottage and Sherman, Figures of Invention, n 9 above. See also K Murray, A Politics of Patent Law: Crafting the Patent Participatory Bargain (Routledge 2014).

${ }^{52}$ Dan L Burk and Jessica Reyman, 'Patents as Genre: A Prospectus' (2014) 26 Law and Literature 163. The authors use genre theory methodology to draw out the social role played by patents discussing both linguistic characteristics of the patent document as well as its social character as the product of a community of patent practitioners. Hyo Yoon Kang similarly adopts narrative analysis as a tool to analyse the nature of the reality of human biotechnology and intellectual property; and sees a system that lacks a self-reflexive understanding of its own practice, 'An Exploration into Law and Narratives: The Case of Intellectual Property Law of Biotechnology' H.Y. Law Critique (2006) 17: 239. 
what the rhetorical features of patent documents reveal about the workings of the patent system and the underlying ideologies of the patent community. ${ }^{53}$

Importantly, these authors contextualize patents in the social world to bring attention to the process by which patents as texts are created. In both accounts meaning-making and agency is diffused amongst the entire patent system or patent community, which deflects the possibility that many of these dynamics are deliberate and driven by institutional forces that set out to create and replenish epistemic communities for specific purposes. In contrast, my focus on textualisation as it arises in implementing patent offices specifically interrogates the agency of the patent offices while also taking note of the community based conventions that revolve around them. ${ }^{54}$

\section{Textualisation}

Operationalising substantive and broadly worded content into formulaic instructions to patent applicants is necessarily prone to uncertainty within a regulatory environment. It is in this context that we find that patent offices routinely textualise substantive content. I define textualisation as a mode of persuasion that uses linguistic and rhetorical arrangements to cumulatively and credibly communicate legal positions. As the examples and observations in this paper will demonstrate it

\footnotetext{
${ }^{53}$ A view that fits well with new institutionalism's perspective on the transformative power of rhetoric in the relationship between law and politics. See for instance Susan R Burgess, 'Beyond Instrumental Politics: The New Institutionalism, Legal Rhetoric and Judicial Supremacy' (Spring 1993) 25 Polity 3, 445-459.

${ }^{54}$ I borrow from Latour's work on 'textualisation' as he presents the scientific article as a rhetorical vehicle that gives agency to technoscience (Latour, Science in Action, n 10 above). Also see discussion of Foucault's work in Saul Cornell, 'Splitting the Difference: Textualism, Contextualism and PostModern History' (Spring 1995) American Studies Vol 36, Issue 1, 57-80.
} 
facilitates the management of disputed or uncertain legal positions. The textual arrangements in Examination Guidelines do not reference purpose or normative standards and are often framed in a way that makes disagreement or critical scrutiny difficult. In so far as textualisation is the dominant constitutive heuristic of legal standards in patent law and for reasons examined in detail below, it is an appropriate tool to interrogate the legitimacy of patent law. While textualisation can materialize in other areas of the law ${ }^{55}$ what makes it particularly relevant to patent law is the ubiquity of 'technolaw' 56 - an intermediate product in action of law and technology necessitating nonstandard language and expressions.

Myers, for instance, observes how stylistic arrangements generate a gap between science and the legal and commercial implications of technology. His analysis of patent claim language is ultimately guided by examination guidelines (although this remains implicit in his work) that instruct on claiming particular categories of inventions. He observes that final claims are one long noun phrase, making each indivisible claim a single speech act, longer than any sentence that might be written in academic prose. The construction of the noun phrase means crucial information in each claim is embedded several layers deep. Pronouns, ellipses and substitutions that would normally be used in prose are rejected in favour of explicit referents. Yet the strategic implications of the relation between referents is left unsaid. There is also a common use of superordinate categories - substances, processes or functions described in broad terms that could usefully extend the application of the claims. The text of the patent draws and blurs the boundaries between scientific, legal

\footnotetext{
${ }^{55}$ A version of it manifests in common law. See Peter M Tiersma, 'The Textualisation of Precedent' (2013) 82 Notre Dame Law Review 1187.

${ }^{56}$ Mirroring Latour's technoscience, n 10 above.
} 
and commercial needs, between 'the academic world of making knowledge and the legal world of owning things' ${ }^{57}$ Technolaw begins to emerge and stabilise in this contorted world of unconventional usage.

Patents above all are legal documents ${ }^{58}$ and in addition to the complexity of defining an invention in words, there are specific modalities that arise when technical facts are used to populate legal standards. Take inventive step ${ }^{59}$ for instance. Ultimately inventive step is a legal standard, but it relies on credible markers of average technical skill and knowledge that is specific to a field. What does an average person skilled in that particular art make of the invention - based on common general knowledge and in comparison to prior art would she consider the invention to be an obvious development? If yes, then it will not merit a patent. In order to understand how these decisions are made we need to know who the notional person skilled in the art is, what she knows, and how she behaves. ${ }^{60}$ These are often expressed as technical facts: 'the average person already knew that $x$ causes $y$, and also that $y$ is closely related to $y l^{\prime}$. The patentability of $\mathrm{x}$ for $\mathrm{y} 1$ will therefore pivot on how easily the average person skilled in the art would associate y and y1. A decision on

\footnotetext{
${ }^{57}$ Myers, n 46 above, 101.

${ }^{58}$ Kirin Amgen Inc v Hoechst Marion Rousel Ltd [2004] UKHL 46, [33]-[34].

${ }^{59}$ Defined in the EPC, art 56 (and similarly in the Patents Act 1977, s3): ‘An invention shall be considered as involving an inventive step if, having regard to the state of the art, it is not obvious to a person skilled in the art.'

${ }^{60}$ In the UK technical facts and legal analysis are marshalled using the structured approach in Windsurfing International Inc v Tabur Marine (Great Britain) Ltd [1985] RPC 59.
} 
inventiveness leading to patentability here will almost certainly involve technical or expert evidence. ${ }^{61}$

Technolaw is an intermediary of legal and technical standards that allows for the operationalisation of legal doctrine within a given technological context. Even a simple reading of patent claims will show that there is no prose quite like it - there is no straightforward epistemic transfer of terminology between science and law.

Meaning depends on the robustness of myriad claims - scientific, legal and commercial that is embedded within the dialect - it is the genealogy of the terms and conventions $^{62}$ that develop or are instigated around it that allows for meaning to be built up. The veracity and facticity of a technolegal object depends on the chain of referents that work to make it stable, much like in most well accepted definitions of Latour's technoscience. The opportunity for manipulation in meaning is considerable. Technolaw is material to a number of standards, such as novelty, enablement, sufficiency of disclosure and construction of claims. It is the inevitability of technolaw, together with the institutional entrenchment that makes textualisation a potentially distorting process in patent law.

While textualisation may be cultivated by patent communities patent offices often steer the phenomenon. ${ }^{63}$ In invoking textualisation the patent office may be

\footnotetext{
${ }^{61}$ A process subject to some unusual pitfalls. See Arnold J's decision in American Science \& Engineering Inc v Rapiscan Systems Ltd [2016] EWHC 756 (Pat) at [109]-[111] on the nearly impossible task of not using in a decision on obviousness.

${ }^{62}$ For instance see Secretary of State for Education and Skills v Frontline Technology Ltd Unreported, 17 June 2004, about the term 'download' which is now in common parlance. But would its use ten years ago have a different, more restrictive meaning? As discussed in R Davis, 'Claim Drafting' in Roughton et al., n 35 above.

${ }^{63}$ Alvesson's institutionalist grounding of rhetoric as being closely tied to agency, knowledge and
} 
implicitly and explicitly taking into account the 'needs' of any one part of the constituent patent community, while also managing other needs selectively as seen in the following two manifestations of textualisation under the EPC - diagnostic methods and Swiss-type claims for new medical uses. ${ }^{64}$

In both cases the Examination Guidelines and the instructions on claim language take on the structure of highly technical documents. The legal position is presented as ahistoric, undergoing frequent updates and edits, without full reference to the twists and turns of interpretation that have dissolved into the current position. Potential dissent is often anticipated, and there is frequent appeal to supportive authority and almost no reference to counter authority. The result is a highly defensive style where outcomes are framed as uncontroversial - a technique that Latour terms 'stratification' ${ }^{65}$ that feeds his constructivist depictions of networks in technoscience' and one that is emulated within technolaw.

ambiguity is relevant to explore how textualisation may allow actors like patent examiners and judges to give accelerated directionality to the law (Mats Alvesson and Dan Karreman, 'Taking the Linguistic Turn in Organizational Research: Challenges, Responses, Consequences' (2000) Journal of Applied Behavioral Science, 36, 136-158; Mats Alvesson, 'Organizations as Rhetoric: Knowledge-Intensive Firms and the Struggle with Ambiguity’ (1993) Journal of Management Studies, 30, 997-1015).

${ }^{64}$ In using case studies I am following legal scholars who have used empirically validated observations to predicate analytical institutional perspectives. See Mark C Suchman and Lauren B Edelman, 'Legal Rational Myths: The New Institutionalism and the Law and Society Tradition' (1996) 21 Law \& Soc. Inquiry 903 (<http://scholarship.law.berkeley.edu/facpubs/475 $\geq$ accessed 16 September 2016); Nicola Lacey, The Jurisprudence Annual Lecture 2013 - Institutionalising Responsibility: Implications for Jurisprudence, 4 JURISPRUDENCE 1, 1-19 (2013); Julia Black, 'New Institutionalism and Naturalism in Socio-Legal Analysis: Institutionalist Approaches to Regulatory Decision Making’ (January 1997) Law and Policy 51.

${ }^{65} \mathrm{n} 10$ above, 48. 
The methodology of using examination guidelines as an intermediary text, in order to observe and interpret how the patent community including examiners and patent agents use and modify it, does not however, map Latour's anthropological field study of human and non human agents in scientific practice. My analysis nonetheless sets the stage for fuller empirical observations and analysis of the materiality and significance of the guidelines - including who drafts them, who edits different versions, concrete use and non-use by examiners, their use in claim drafting and litigation, their instrumental use in policy making and international negotiations etc.In Science in Action Latour depicts science as a textual activity, where narrative and the power to persuade are intrinsic to the success of the activity. What my work shares with the many science and technology studies that build on or challenege Latour's constructivist position, is the aspiration around transparent language and in the 'irrepressible belief in the possibility of writing truer texts.' 66

Textual arrangements and discursive practices such as appeal to allies, supporting texts or authorities, or excessive reliance on technical markers of credibility are some of the elements that are constitutive of knowledge claims in technical documents. These tend to proliferate and dominate as controversy flares. Using the scientific article as a vehicle, Latour shows how stratification can weaken and mute disagreement. The scientific article stages and frames to address and draw in potential dissenters - 'the transformation of linear prose into, so to speak, a folded array of successive defence lines is that surest sign that a text has become scientific. ${ }^{67}$ In patent examination guidelines too, concepts, standards or definitions go through a

\footnotetext{
${ }^{66}$ Bruno Latour, 'The politics of explanation' in Steve Woolgar (ed), in Knowledge and Reflexivity: New Frontiers in the Sociology of Knowledge (Sage 1988), 168.

${ }^{67} \mathrm{n} 10$ above, 48.
} 
process of stabilisation where meaning is mooted, developed and transformed into accepted, or legitimate, legal standards.

Stratification leads to complex and difficult to penetrate texts, creating black boxes in the process - where the inputs and outputs of science become routine and accessible, but the internal workings and the processes whereby scientific knowledge is produced itself become inaccessible. ${ }^{68}$ Latour also recognized that scientific and technical work is made invisible by its own success ${ }^{69}-$ a view that translates well to success as legitimacy in technolaw. The pinnacle of such 'success' may involve de jure acceptance of textualised language by a duly constituted legislature (as in the case of medical use claims discussed below) or when an appellate judicial body accepts a de facto textualised outcome as a substantive norm, as seen arguably, in the case of industrial application in European and UK patent law. ${ }^{70}$

\footnotetext{
${ }^{68}$ A term from cybernetics that denotes a piece of machinery or set of commands that are too complex to work with routinely - a piece of kit denoted only by input and output. See Trevor J Pinch, 'Opening Black Boxes, Science, Technology and Society' 1992 Social Studies of Science 22(3) 487-510, at 488 attributing the first use of black boxism to R Whiteley's criticism of Mertonian studies. For a more general critique see Frank Pasquale, The Black Box Society (Harvard University Press 2015).

69 'When a machine runs efficiently, when a matter of fact is settled, one need focus only on its inputs and outputs not on its internal complexity. Thus paradoxically, the more science and technology succeed, the more opaque and obscure they become.' Bruno Latour, Pandora's hope: Essays on the Reality of Science Studies (Harvard University Press 1999).

${ }^{70}$ In Human Genome Sciences (n 35 above) the UK Supreme Court (SC) did not probe the provenance of the fifteen principles derived from EPO decisions to give content to industrial application. The SC assumed that the principles must be true to the EPC while skipping the transplantation of US terms derived from examining practice into the EPO's decisions - something the court had declined explicitly to do in the same judgement because of the 'obvious risks' of such a 'deeply flawed' move. See
} 
A dissenter who faces a black box in a technical document has only three recourses open to him - 'giving up (the most likely outcome), going along, or working again through what the author did ${ }^{71}$ to begin building up contrary evidence to support a dissenting view. The third option is a resource-intensive process of reexamining how controversial positions are settled, the costs of which can contribute to making such positions in technolegal domains legitimate. When juxtaposed against the ambiguous status of Examination Guidelines where they are not law per se, but nonetheless feed legitimate expectations within the practice community, legal axioms presented as black boxes can give accelerated directionality to legal standards.

New knowledge does not have to be accepted by all or even a large majority in order to be considered as a black box. It is a 'sufficient condition that it is a constituent in any ongoing network. ${ }^{, 72}$ In terms of organisational legitimacy there is no need for a certain version of legal rules to be accepted by all constituencies of the patent community as legitimate to be perceived as such by some groups who then build on these 'taken for granted' rules. In order to understand these signifiers of legitimacy fully, it is essential to analytically examine patent law as it is being made, before text becomes stratified, before the box closes and legal rules become defaults.

Sivaramjani Thambisetty, 'Legal Transplants in Patent Law: Why "Utility” is the New "Industrial Applicability"” (2009) 49 Jurimetrics Journal 155.

${ }^{71} \mathrm{n} 10$ above, 63.

${ }^{72}$ Y Yonay, 'When Black Boxes Clash: Competing Ideas of What Science is in Economics, 1924-39' 1994 Social Studies of Science 24(1) 39-80 at 42. 


\section{Case Studies}

\section{A. Diagnostic Methods}

Diagnostic methods for humans and animals have a long history of being prohibited from patentability. ${ }^{73}$ Strong socio-economic policy reasons for the exclusion have facilitated statutory inclusion in a number of jurisdictions. ${ }^{74}$ Yet Examination Guidelines based on the Enlarged Board of Appeal's decision (Enlarged Board) in Diagnostic Methods G 1/04 set out a very narrow interpretation of the exclusion that appears to reserve the entire weight of the scope of this exclusion only to the most unskilled patent applicant. ${ }^{75}$ The claim language is a direct result of the decision of the Enlarged Board. On the one hand it could be said that the Examination Guidelines reflect the position taken there. On the other hand, remarkable characteristics of the language demonstrate textualisation and extrapolate the decision in $\mathrm{G} 1 / 04 .{ }^{76}$

In presenting the controversial position as final outcomes, the Examination Guidelines paper over the intense disagreements that preceded the resolved position. ${ }^{77}$

\footnotetext{
${ }^{73}$ It mirrors the history of the exclusion of methods of medical treatment. See Tina Piper, 'A Common Law Prescription for a Medical Malaise’ in Catherine W Ng, Lionel Bently and Giuseppina D’Agostino, The Common Law of Intellectual Property: Essays in Honour of David Vaver (Hart Publishing 2010).

74 TRIPS Agreement, art 27; Patents Act 1977, s 4A(1); EPC, art 53(c).

${ }^{75}$ G 1/04 OJ 2006, 334. The decision on appeal to the Enlarged Board usually indicates the need to reconcile divergent interpretations coming from the Boards of Appeal.

${ }^{76}$ EPO Examination Guidelines, pt G - ch II-14 4.2.1.3.

${ }^{77}$ In making the case for the referral on appeal, the President of the EPO extensively set out a number of conflicting decisions of the Boards of Appeal (G 1/04 n 76 above). The most relevant decisions were T 385/86 OJ 1988, 308 which excluded a method only if it resulted in the decision to adopt a particular course of medical treatment; and the claim contained all the steps involved in reaching a medical diagnosis; and T 964/99 OJ 2002, 004 which gave a much broader interpretation to hold a method
} 
One of the ways in which this is done is by expressing the final position-namely that a number of different kinds of diagnostic methods are in fact patentable - in bite-sized increments that direct you methodically towards the final outcome. The increments themselves go either towards or away from patentability ${ }^{78}$ but taken as a whole there can be no doubt that the position is one that makes it fairly easy to obtain a patent on a diagnostic method.

The Examination Guidelines based on G 1/04 state that for a 'diagnostic method' to be practiced on 'the human or animal body' direct physical contact with the body is not required. But it does so by saying that 'each of the multiple technical steps' in the diagnostic methods must be 'performed' on a human or animal body, and that for each such step we must ascertain if there has been 'an interaction' with the human or animal body. Such interaction is not determined by type and intensity, only by the 'presence' of a human or animal body. ${ }^{79}$

The substantive statutory requirement of 'practiced on the human or animal body $^{90}$ is overwhelmed by a successive dilution in terminology - practiced to performed to interaction to mere presence - such that no actual physical contact with the body is necessary. In effect, the type of interaction with the human or animal body is irrelevant to patentability such that visual observation, $\mathrm{X}$-rays and invasive techniques would all equally qualify. Each of these terms is collated in G 1/04 from a number of previous Board of Appeal decisions where least common denominators of 'interaction' appear to have been set out in no particular coherent order. So framed,

excluded if it contained at least one step of diagnostic character which was practiced on a living human or animal body.

${ }^{78}$ Similar to Latour's positive and negative modalities (n 10 above).

${ }^{79}$ EPO Examination Guidelines pt G - ch II-14 4.2.1.3.

${ }^{80} \mathrm{EPC}$, art 53(c). 
the stipulation that the diagnostic method be 'practiced on human or animal body' has the potential to filter out a greater number of methods than if the actual presence of a human or animal body were required. This increment therefore makes it more difficult to patent a diagnostic method.

The text of the Examination Guidelines also exhibits stratification:

The difference between a regular text in prose and a technical document is the stratification of the latter. The text is arranged in layers. Each claim is interrupted by references outside the text or inside the text to other parts, to figures, to columns, tables, legends, graphs. Each of these in turn may send you back to other parts of the same text or to more outside references. In such a stratified text, the reader once interested in reading it, is as free as a rat in a maze. $^{81}$

The key question is whether a claim in a patent application is directed towards a diagnostic method. The Examination Guidelines for Article 53(c) of the EPC state: ${ }^{82}$ The claim must include method steps relating to all of the following phases:

(i) the examination phase, involving the collection of data,

(ii) the comparison of these data with standard values,

(iii) the finding of any significant deviation, i.e. a symptom, during the comparison,

(iv) the attribution of the deviation to a particular clinical picture, i.e. the deductive medical or veterinary decision phase (diagnosis for curative purposes stricto sensu).

\footnotetext{
${ }^{81} \mathrm{n} 10$ above, 48.

${ }^{82}$ EPO Examination Guidelines pt G - ch II-14 4.2.1.3. Bold highlighting as in original text.
} 
If features pertaining to any of these phases are missing and are essential for the definition of the invention, those features are to be included in the independent claim (see Example 9 in Annex II of F-IV). Due account should be taken of steps which may be considered to be implicit: for example, steps relating to the comparison of data with standard values (phase (ii)) may imply the finding of a significant deviation (phase (iii) - see T1197/02). The deductive medical or veterinary decision phase (iv), i.e. the "diagnosis for curative purposes stricto sensu", is the determination of the nature of a medical or veterinary medicinal condition intended to identify or uncover a pathology; the identification of the underlying disease is not required (see $\mathrm{T} 125 / 02)$.

One of the ways in which stratification manifests in this paragraph is by the splitting up of a claim into several diagnostic method steps itself not a term of art in the EPC. These 'phases' of diagnostic method claims are presented in language redolent of medical or veterinarian phraseology that function as technical markers of credibility.

Stipulating that the final phase does not need to relate to a disease, but must merely be intended to uncover a pathology appears to be strengthening the impact of this exclusion, by including within its ambit 'mere pathologies'. The reader is then directed towards citations to legal decisions which are supportive decisions of different boards of the same tribunal ${ }^{83}$ - the equivalent of repeating oneself to gain authority - while ignoring a similar number of Board of Appeal decisions that lead to the opposite conclusion.

\footnotetext{
${ }^{83}$ See discussion of divergent case law in G 1/04, n 76 above.
} 
The overall directionality of stratification becomes clear in the first sentence when the Examination Guidelines stipulate that the claims must include all of these phases in order to be a true 'diagnostic method' (and therefore not patentable). There is a triple negative here that is also put to great use: 'If all the phases are not present, then it is not a diagnostic method, and is therefore not excluded.' In other words, to patent a diagnostic method all you have to do is avoid these phases in sequence in the claims, which will not be hard to do as they are in fact a construct that can be sidestepped by the patent applicant either by showing that not all the stipulated phases are reflected in his/her claim, ${ }^{84}$ or by showing that even though all the phases are present in his/her claim, one or more of them are 'not practiced on/performed on/do not interact with a human or animal body'. The result is the creation of multiple loopholes in the law that can be exploited even by the most un-opportunistic patent applicant who seeks to patent a diagnostic method.

There are at least three observations one can make that in effect deepen textualisation in this example. Firstly, we see no allusion to the purpose or function of the exclusion of diagnostic methods on patentability. This has the effect of muting the long history of policy reasoning behind this exclusion. Secondly, these guidelines present as settled a deeply controversial area of the law and one that was subject to contradictory decisions not so long ago. There is no hint of this controversy in the Examination Guidelines. Thirdly, the law still says 'diagnostic methods' are excluded, and therefore potential dissenters are subdued if not silenced, except now we have a

\footnotetext{
${ }^{84}$ In G 1/04 the Enlarged Board asserted that this kind of circumvention 'does not seem to pose a real risk having regard to well-established jurisprudence at the EPO in respect of Art 84 EPC, which requires that in order to be patentable an independent claim must recite all the essential features which are necessary for clearly and completely defining an invention.' $\mathrm{n} 76$ above at [6.2.4].
} 
newly constructed meaning of 'diagnostic method' that has a life only in the Examination Guidelines. The overall impact is of text that is self-assured and persuasive. Reaching into the legal, policy and interpretational reasoning in order to place this text in the context of the disagreements it arose from requires the reader to be an insider - not just to the law, but also to the particularities of the technical language that forms the scaffold to the final interpretative position. The result is a text that, on its own, is almost impervious to critical scrutiny.

\section{B. Swiss Claims}

An understanding of Swiss-type use claims ${ }^{85}$ begins with an understanding of novelty in patent law. Generally only something that is new (and inventive) can be patented and novelty is only tested by reference to the state of the art prior to the priority date ${ }^{86}$ Historically it has been defined in various ways, ranging from selective timelines for prior art documents and differing grace periods ${ }^{87}$ to 'absolute novelty'. ${ }^{88}$ A full examination of novelty in all its forms is not pivotal to my argument, but one of the fundamental rationales of the novelty standard is that a patent should not prevent someone doing what they were free to do before it was granted. This is called the

\footnotetext{
${ }^{85}$ First approved by the EPO in 1984 by G 5/83 OJ 1985, 064.

${ }^{86}$ Hector MacQueen, Charlotte Waelde, Graeme Laurie and Abbe Brown, Contemporary Intellectual Property: Law and Policy, (2nd edn, Oxford University Press 2010) 450.

${ }^{87}$ Kate H Murashige, Harmonization of Patent Laws, 16 Hous. J. Int'l L. 591, 610-11 (1994) (describing limited grace periods available under Japanese, Australian, and Canadian law).

${ }^{88}$ The standard adopted by the UKPA 1977 and the EPC with no temporal or geographical restriction on the prior art. See discussion in Catherine Colston and Jonathan Galloway, Modern Intellectual Property Law (3rd edn, Routledge 2010) 168; Toshiko Takenaka, Rethinking the United States FirstTo-Invent Principle From a Comparative Law Perspective: A Proposal to Restructure $\$ 102$ Novelty and Priority Provisions, 39 Hous. L. Rev. 621, 626-29, 663 (2002).
} 
'right to work' principle and it protects against a 'bad monopoly which takes from the public that which it already has or could readily have without the added incentive of the patent right. ${ }^{89}$

Normally, when a chemical product is patented or 'been made available ${ }^{90}$ all of its routine qualities, attributes and uses become known and are no longer novel. This is the case even if those qualities are not explicitly detailed in the patent application but are a matter of implicit disclosure based on common general knowledge..$^{91}$ The general rule for uses that have not been specifically described, even if the product is known is that if the product is in a form in which it is in fact suitable for the stated use, that use would no longer be new. This is because 'no man can have a patent for merely ascertaining the properties of a known substance' ${ }^{92}$

This assumption creates a difficulty in the case of pharmaceutical products with known therapeutic effects that yield other, explicitly unpatented therapeutic uses.

\footnotetext{
${ }^{89}$ Judge Giles Rich 'Escaping the Tyranny of Words - Is Evolution in Legal Thinking Impossible?', (1978) 60(5) JPOS 271, 288. For a modern explanation of the 'test of reverse infringement' that secures the right to work, see Synthon BV v Smithkline Beecham plc [2006] RPC 10.

${ }^{90}$ An invention is anticipated (that is, it is no longer novel) as long as it has been made available to the public. See G 1/92 OJ 1993, 277 [1993] EPOR 241.

${ }^{91}$ H Lundbeck A/S v Norpharma SPA [2011] RPC 23 where Floyd J confirmed that prior disclosure includes implicit disclosure.

${ }^{92}$ I. G. Farbenindustrie A.G. 's Patents, (1930) 47 RPC at [322]. This general principle is also the location of a major fault line of diverging practice between the EPO and the UKIPO. In G 2/88 OJ EPO 4/90 and G 6/88 OJ EPO 490 the Enlarged Board held that a claim to the use of a known compound for a certain purpose based on a technical effect described in the patent should be regarded as a functional technical feature which remains novel if this feature has not previously been made available to the public. But see UK Manual of Patent Office Practice 2.14 at <https://www.gov.uk/guidance/manual-ofpatent-practice-mopp/section-2-novelty $\geq$ accessed 16 September 2016.
} 
This is a common occurrence as once a product has been used for a therapeutic purpose it is deemed safe making the potential benefits of experimentation much higher than in an untested product. So an exception to the general rule largely in response to demands by the pharmaceutical industry was incorporated in the EPC 1973. It allowed new medical uses of patented products to be protected with a separate and limited patent on the newly discovered medical use, which for the purposes of the grant of the patent was deemed to be novel..$^{93}$

Deemed novelty of this kind is, of course, within the remit of what a legitimately established legislative process can achieve. There arose however the problem of further 'new' medical uses that became apparent as more and more research was done on the same tried and tested products. ${ }^{94}$ These uses come in a number of forms - for example, they relate to new diseases or to new dosage regimes with fewer side effects or increased efficacy (not necessarily therapeutic efficacy). ${ }^{95}$

As a general principle if a statute specifies one thing (here first medical use) and does not specify it as an example of a particular class of things then everything

\footnotetext{
${ }^{93}$ EPC 1973, art 54(4) (art 54(5) in EPC 2000, also see art 54(4)).

${ }^{94}$ Eventually including those with non-medical uses. See G 2/88 OJ 1990, 093.

${ }^{95}$ Since G 5/83 (n 86 above) Boards of Appeal began to accept 'mere distinguishing features' other than treatment of a different disease as constitutive of novelty, including a new dosage regime, new class of patients being treated, new modes and routes of administration of a known substance. Such claims prise open the door for claims based on nothing more than new information (sometimes of the kind that may be obtained by a doctor in the course of administration of a drug) about known things. See list of TBA cases in G 2/08 OJ 2010, 100. In the UK since Wyeth [1985] RPC 545 and BristolMyers Squibb v Baker Norton [2001] RPC 1, Swiss-type use claims have been accepted although the UK had long stopped short of accepting dosage claims as novel, a position that was reversed by the Court of Appeal in Actavis v Merck [2008] EWCA Civ 444, [2009] 1 WLR 1186. See N Jenkins, 'Pharmaceuticals: First and Second Medical Use Claims' in Roughton et al. n 35 above, 119-127.
} 
except the specified thing is deemed to have been expressly excluded. In $G 5 / 83,{ }^{96}$ the Enlarged Board ruled that expressio unius est exclusio alterius ${ }^{97}$ did not apply here, and legislating to provide patent protection to the first medical use of a known (not new) substance did not exclude the possibility of second and further medical uses also becoming eligible for patent protection. Practically this decision opens the way for old or known products to leach novel 'medical uses', potentially indefinitely.

The arrangement of language in the Swiss-type use claim is fashioned by a combination of this history of second and subsequent medical uses with another important exclusion in patent law. Methods of medical treatment of humans or animals like diagnostic methods, have a long history of being excluded dating back to the professionalisation of medicine when it was deemed important to remove snake oil merchants and their sales talk from the ambit of what a credible and self-regulated body of professionals should be free to do without the pressures of commerce. ${ }^{98}$ Until recently this exclusion was expressed as follows: 'Methods of medical treatment are not industrially applicable ${ }^{99}$ This is an allusion to medical treatment being excluded as they do not belong in the commercial sphere. ${ }^{100}$

\footnotetext{
${ }^{96}$ n 80 above.

${ }^{97}$ The expression of one subject, object, or idea is the exclusion of other subjects, objects, or ideas. See Clifton Williams, 'Expressio Unius Est Exclusio Alterius' (1931) 15 Marquette Law Review 4, 191.

${ }^{98}$ See generally Piper, n 74 above.

${ }^{99}$ EPC 1973, art 52(4) (replaced in EPC 2000 by art 53(c)).

${ }^{100}$ In itself a controversial conclusion for 'the evil sought to be avoided - a monopoly on a healing art

- is a necessary pre-condition for the good sought - the specific advance in medical science'. G F

Burch, 'Ethical Considerations in the Patenting of Medical Processes' (1987) 65 Texas Law Review

1139 as cited in Todd Martin, 'Patentability of Methods of Medical Treatment: A Comparative Study'

(2000) 82 Journal of the Patent and Trademark Office Society 381.
} 
The methods of medical treatment exclusion presented a conundrum to the EPO that had to follow up on its promise of patent protection to second and subsequent medical use. If we denote the product as $\mathrm{x}$, and $\mathrm{y}$ as the first medical use and y1 as the second medical use, the following is the problem and solution in claim language:

A. $x$ for the use of $y$-is already patented.

B. $x$ for the use of $y 1$ - cannot be patented as the statute only allows for the first use to be patented.

C. $x$ for the treatment of $y 1-$ is not appropriate because this form of claim is a method of medical treatment which is excluded.

The solution of Swiss-type use claim:

D. use of compound $x$ in the manufacture of a medicament for the treatment of the disorder $y 1$ - can be patented.

The Swiss-type use claim in D claims the same subject matter as in C above, except that the addition of manufacture of medicament allows D to escape the explicit exclusion because it alludes to an industrial use. If it has industrial use, it cannot be a method of medical treatment because methods of medical treatment do not have industrial application as per the old Article 52(4). By this reasoning, the following two claims would not have been patentable under EPC 1973 where both uses are beyond the first medical use:

'Product X for use in the treatment of cancer'

or

'Product X for use in the treatment of leukaemia'

But the following Swiss-type use claim of the invention becomes patentable. 
'The use of Product $X$ for the manufacture of a medicament for the treatment of cancer/leukaemia'. ${ }^{101}$

The narrative intent in this claim type is to create a descriptor without any real change in circumstances (ie the invention is the same - essentially a method of medical treatment). With respect to novelty, the manufacture of the medicament itself does not have to be a new method of manufacture ${ }^{102}$ because the novelty of the Swisstype use claim is, in the words of the EPO 'derived by analogy from the new therapeutic application rather than the process of manufacturing the medicament.. ${ }^{103}$ There is therefore no real functional relationship between novelty of the use and the method of manufacture - so the reformulated claim type has no 'meaning' in the conventional sense. Rather, novelty by analogy or a notional novelty that cannot in effect be transposed ${ }^{104}$ is used to bolster the arrangement. In the context of textualisation I see the use of notional novelty and the term 'manufacture of medicament' as rhetorical devices.

What is the net effect of Swiss-type use claims in the real world? Pharmaceutical companies can now claim multiple layers of property rights over the same thing, a process that facilitates rent-seeking behaviour by preventing someone from doing what they might have been free to do before the patent on the second or subsequent medical use was granted. It waters down the rationale for novelty and it does so not with appeal to public interest or purpose but by the application of a textual

\footnotetext{
${ }^{101}$ See EPO Examination Guidelines pt G - ch VI-4 [7.1] (Table showing allowable claims).

102 Jenkins, n 96 above, 124.

${ }^{103}$ Enlarged Board in G 5/83 (n 86 above) at [21]. Further, 'it is to be clearly understood that the application of this special approach to the derivation of novelty can only be applied to claims to the use of substances or compositions intended for use in a method referred to in Art 52(4) EPC'.

${ }^{104} \mathrm{G} 2 / 08$ (n 96 above) at [III.4].
} 
artifice. Nowhere in the current Examination Guidelines are the controversial public interest issues or a purposive approach within the context of the patent statute ever raised.

Furthermore, in the time between its entry into the discussion after the Eisai decision and EPC 2000, the Swiss-use claim has in essence, been transformed from a rhetorical oddity to substantive law. Two steps heralded the death of the Swiss-type use claim. The first was an amendment in the revised EPC 2000 to the exclusion of methods of medical treatment on the grounds of not being industrially applicable, to just being excluded - thus 'methods of medical treatment are not patentable. ${ }^{\text {, }}{ }^{\text {It }}$ It had become difficult to reason this exclusion as though it were a matter of legal interpretation rather than direct policy particularly in national courts. ${ }^{106}$ Rather disingenuously, this change was consequently characterized by the EPO as 'a mere editorial change' without substantive legal content. ${ }^{107}$

Once this change is in effect patent applicants are free from the straightjacket of the Swiss-type use claim because now there is no need to claim it in the form of 'manufacture of a medicament' and a second amendment was introduced. ${ }^{108}$ Taken

\footnotetext{
${ }^{105} \mathrm{EPC}$, art 53(c).

${ }^{106}$ In Eli Lilly's and Co's Application [1975] RPC 438 the court stated that 'the reasons for such an exclusion appear to us to be based in ethics rather than logic'.
}

${ }^{107}$ According to point 6 of the explanatory remarks concerning 'transitional provisions' the shifting of the former provisions of art 52(4) of the EPC 1973 to the new art 53(c) of the EPC 2000 'does not change the actual legal position' (OJ EPO 2001).

${ }^{108}$ Art 54(5) states Paragraphs 2 and 3 [of Art 54 of the EPC] shall also not exclude the patentability of any substance or composition referred to in paragraph 4 [any substance or composition, comprised in the state of the art] for any specific use in a method referred to in Article 53(c) [methods for treatment of the human or animal body by surgery or therapy and diagnostic methods practiced on the human or 
together the two amendments pave the way for claims on new uses of known (patented) substances in the form 'Use of $x$ for use in medical treatment of $y$ ' - now called the medical use claim. ${ }^{109}$

The text in the Examination Guidelines is full of tables comparing and contrasting methods of medical treatment that are and are not patentable, and previous Swiss-type use claims that should now be claimed in the form of medical use claims. ${ }^{110}$ The dense interconnections in the text is an appeal to technical credibility and contribute to the persuasive appeal of the Examination Guidelines.

Article 54(5) effectively culls the Swiss-type use claim, but like the dragon serpent hydra that produces two new heads for each that is decapitated it has produced two legislative changes that gained support at least partly because the practice of such claims generated legitimate expectations in the period between the decision in Eisai and EPC 2000. In Latourian terms, the Swiss-type use claim was law in the making and the medical use claim, an attempt to black box facts. ${ }^{111}$ As incoherent as the Swiss-type use claim is, its staged transformation to substantive law is definitive of the reach of textualisation.

Interestingly once the consequences of EPC 2000 were confirmed, the UKIPO has said this about hard-to-justify anomalies that are Swiss-type claims:

Specifically, Swiss-type claims are considered to be unclear because, although they define a method of manufacturing a medicament, the invention does not

\footnotetext{
animal body], provided that such use is not comprised in the state of the art. Only applies to where decisions to grant a patent are taken on or after 13 December 2007.

${ }^{109}$ See EPO Examination Guidelines [7.1.1] and [7.1.2.] and [7.1.3] including tables listing correct claim language.

110 ibid.

${ }^{111}$ Latour, n 10 above, r 1.
} 
in fact relate to the method of production but instead relates to the intended use of the medicament. As stated in G02/08, there is no functional relationship between the feature conferring novelty (the intended use) and the claimed manufacturing process. As Section 4A(4) now allows a simpler and clearer form of second medical use claim, there is no longer a reason to allow the more ambiguous Swiss form of claim. ${ }^{112}$

The Swiss-type use claim is a successfully textualised outcome - even where it is rejected it is part of the lexicon of patent law. It has to be contended with and a departure explained, if not justified. Several jurisdictions allow such claims and others have recently introduced them including New Zealand in $2009^{113}$ and Singapore in 2011. ${ }^{114}$ In Thailand following a decision to reject Swiss-type use claims in $2011^{115}$ such claims are no longer entertained. This is also the case in the recently drafted Indian Examination Guidelines for pharmaceuticals. ${ }^{116}$

\footnotetext{
${ }^{112}$ UKIPO Practice Note 26 May 2010.

${ }^{113}$ Intellectual Property Office of New Zealand Guidelines at <http://www.iponz.govt.nz/cms/patents/patents-act-1953/patent-topic-guidelines/5.-examination-ofpatent-applications/5.2-guidelines-for-the-examination-of-Swiss-type-claims $\geq$ accessed 16 May 2015. 114 The Singapore Patents Act is closely related to the UK Patents Act 1977. Examining Guidelines from the Intellectual Property Office of Singapore at <https://www.ipos.gov.sg/Portals/0/Patents/Examination\%20Guidelines\%20for\%20Patent\%20Applicat ions\%20at\%20IPOS_Feb\%202014.pdf $\geq$ accessed 16 May 2015.

${ }^{115}$ At <http://www.mirandah.com/pressroom/item/309-the-end-of-Swiss-type-use-claims-in-thailand $>$ accessed 16 May 2015.

116 'Further, it should be borne in mind that finding the new property of an already known substance does not make the substance novel and/or inventive' at <http://ipindia.nic.in/iponew/draft_Pharma_Guidelines_12August2014.pdf $\geq 6.2$ accessed 16
} 
The ongoing relationship between Swiss-type use claims and the new 'medical use' claims continues to damage the coherence of patent law. In G2/08 ${ }^{117}$ the Enlarged Board of Appeal held that Swiss-type medical use claims are not directed to the same subject matter as the new medical use claim - potentially opening the possibility of the same invention being covered by two patents. It also indicated that the rights conferred by a medical use claim are 'likely broader than those conferred by a Swiss-style claim' and 'could, in particular lead to possible restrictions on the freedom of medical practitioners to prescribe or administer generics. ${ }^{, 18}$ But it also says:

in view of the clear provisions of Art 53(c) second sentence, and 54(5) EPC the intention of the legislator, the Enlarged Board has no power to broaden or reduce in a praetorian way [emphasis added] the scope of these provisions. ${ }^{119}$ Restricting a doctor from prescribing a product that is known and being used for one medical purpose, for another medical purpose goes to the heart of the rationale of novelty and to the integrity of the medical profession. It prevents generic products from expired patents that have rightly fallen into the public domain from being available, an outcome with significant adverse public policy implications.

In the long running UK litigation Mylan and Actavis $v$ Warner-Lambert ${ }^{120}$ Warner-Lambert's patent on Pregabalin for treatment of neuropathic pain was in a

September 2016. Also see Neeti Wilson, 'Patent Office Examination Guidelines for Pharmaceutical Applications’ Journal of Intellectual Property Rights Vol 19 Nov 2014 428-430.

${ }^{117}$ G 2/08 (n 96 above).

118 ibid 6.5. In contrast, Jacob LJ in Actavis v Merck (n 96 above) at 75 observed that the Swiss use claim 'is not aimed at and does not touch the doctor - it is directed at the manufacturer.'

119 ibid 5.9.

${ }^{120}$ [2015] EWHC 2548 (Pat). See [5] for the full case history. 
Swiss-type use form. This is the third medical use of the pharmaceutical compound in question. The litigation raised critical questions whether a doctor or a dispensing pharmacist who prescribes an off-patent version of the drug for one of the patented uses could be infringing the Swiss-use patent. After a decision by the Court of Appeal on the mental elements of infringement ${ }^{121}$ the $\mathrm{HC}$ decided there was no infringement (although the patent was also held invalid). In a move with potential implications for international markets, Arnold $\mathrm{J}$ called for the creation of a new system that of centralised and authoritative guidance for prescribers aimed at balancing the exclusionary effect of monopolies with lawful competition. ${ }^{122}$

Textualisation seen through the lens of the Swiss-type use claim highlights the role of the EPO as quasi-legislator despite the formal status of the Examination Guidelines. It shows how institutional agents can gain purchase for contested legal positions where a more reasoned approach may have failed to garner credible support. The medical use claim black boxes the long and rather tortured history of this claim type. As a successfully textualised outcome, these claims also demonstrate the

\footnotetext{
${ }^{121}$ Warner Lambert v Actavis [2015] EWCA Civ 556.

122 'I remain more convinced than ever that the best solution to the problem of protecting the monopoly conferred by a second medical use patent while allowing lawful generic competition for non-patented indications of the substance in question is to separate the patented market for the substance from the non-patented market by ensuring that prescribers write prescriptions for the patented indication by reference to the patentee's brand name and write prescriptions for non-patented indications by reference to the generic name of the substance (the INN)...Prescribers cannot be expected to know when this is required, nor should they be required to take steps to find out. What is needed is for centralised and authoritative guidance to be given to prescribers as to when this practice should be adopted.' $\mathrm{n} 121$ above, [722]-[723].
} 
capacity to direct far-reaching changes through incremental adjustments while disregarding conventional meaning, context and purpose.

\section{Constructing Legitimacy}

Examination Guidelines occupy an unusual legal space - influential but not law, functional but not substantive. On the face of it, if it is not law no oversight or scrutiny is required yet it remains highly influential of expectations in the patent community that in turn accrues incremental gains for the textualised positions taken up there. Language both constrains and enables choice, and textualisation as a process demonstrates how those choices are expressed and prevail. The two examples discussed are not isolated instances; several of these play out simultaneously and staged transformations of uncertain positions to legal axioms are occurring all the time. ${ }^{123}$ Some of the characteristics of textualisation demonstrated here includes stratified language, highly contextualized definitions, arrangement of negative and positive modalities, rhetorical devices removed from meaning, creation of black boxes and a broad disconnect from purpose, context and normative content. The ahistorical presentation of legal positions and the ambiguous authority of the text mute disagreement.

The increased patentability of diagnostic methods and pharmaceutical use claims are active spheres of contention between patent offices, national courts, emerging economies with newly introduced patent systems, civil society activists and regulators. Monopolisation of critical subject matter through patents often translates

\footnotetext{
${ }^{123}$ Emerging technologies such as synthetic biology in particular could provide fertile ground for textualised outcomes. See discussion in Sivaramjani Thambisetty, 'The Learning Needs of the Patent System and Emerging Technologies: a Focus on Synthetic Biology' (2014) Intellectual Property Quarterly (1), 13-39.
} 
to control over price and access to life-saving or life-enhancing technologies. Such control is often perceived as a manifestation of unfettered or unequal norm setting power. ${ }^{124}$ While some degree of artifice in reasoning is common in the law the scale of such possibilities in Guidelines calls for critical theorists and empiricists to integrate institutional processes including textualisation, in narratives of legitimacy and agency in the patent system.

Conventionally any question of the legitimacy of patent examination guidelines should begin with a question of the legal validity of these guidelines; and from the positivist notion that legitimacy arises from legal status. ${ }^{125}$ Yet the question of the legal validity of the guidelines is unhelpful if not irrelevant. Clearly they are formally legally valid, even if they are not law per se in that the process by which they arise is properly constituted. Yet the lack of oversight, the dyadic split between influential in the sense of driving expectations and steering patent applicant behaviour, and non-law status makes legitimacy rather than legal validity of examination guidelines a far more relevant and productive question.

Although legal validity and legitimacy are related when it comes to normative legitimacy it makes more sense to move away from whether the guidelines should be legitimate (normative basis) to asking whether they are legitimate, ${ }^{126}$ in the sense that legitimacy is an accurate representation of current social facts. Far from being an

\footnotetext{
${ }^{124}$ See Margaret Chon, 'Intellectual Property and the Development Divide' (2006) 27 Cardozo Law Rev 2821-2912.

${ }^{125}$ For a review of the role of legitimacy in legal positivism see Dan Priel, 'The Place of Legitimacy in Legal Theory' (2011) 57 McGill L J 1.

${ }^{126}$ Black, 'Legitimacy and Competition for Regulatory Share', n 6 above, 145-146. Normative legitimacy assessments would confirm perceptions of constitutional or justice claims being met or perceived as being met.
} 
immutable objective fact, legitimacy in organisational, governance or regulatory parlance rests on the acceptability and credibility of the organisation to those it seeks to govern or the relationships it seeks to regulate. ${ }^{127}$ This social constructivist view of legitimacy moves away from the binary of legitimacy as an attribute (where you either have legitimacy or do not); to look at the ways in which an organisation may seek to create, repair or maintain its own legitimacy. ${ }^{128}$

The EPO is part of a regulatory regime of 'interrelated units engaged in joint problem solving to address a particular goal; its boundaries defined by the definition of the problem being addressed, and with continuity over time. ${ }^{129}$ As part of this regime influencing innovation trajectories, the EPO is constantly arbitrating between competing values that may govern the legal protection of inventions. Yet, discordant voices around patent protection has steadily grown over the last few decades as more and more unprecedented subject matter is patented and the goals of public health, ${ }^{130}$ the public benefits of the competitive process, ${ }^{131}$ the need to preserve the public domain ${ }^{132}$ or human dignity ${ }^{133}$ collide with the task of granting patents.

\footnotetext{
${ }^{127}$ David Beetham. The Legitimation of Power (Macmillan 1991).

${ }^{128}$ Black, 'Legitimacy and Competition for Regulatory Share', n 6 above.

${ }^{129}$ Christopher Hood, Henry Rothstein and Robert Baldwin, Government of Risk (Oxford University
} Press 2001), 9-17.

${ }^{130}$ See for instance the basis for the recently concluded report of the UN Secretary General's High Level Panel on Access to Medicines that assumes 'policy incoherence between the justifiable rights of inventors, international human rights law, trade rules and public health in the context of health technologies.'

${ }^{131}$ See European Commission's Final Report on its competition inquiry into the pharmaceutical sector, pursuant to Article 17 of Regulation 1/2003 EC. For this and associated documents see <http://ec.europa.eu/competition/sectors/pharmaceuticals/inquiry/> accessed 16 September 2016.

132 James Boyle, The Public Domain: Enclosing the Commons of the Mind (Caravan books 2008). 
While the EPO has a monopoly on the grant of patents for the member states of the European Patent Convention, the global reach of patentability standards and values that suffuse such standards (through the TRIPs Agreement and bilateral trade agreements for instance) in effect pits it in competition with other national and transnational state and non-state entities that influence innovation including competition authorities. Theoretically, national courts can veer away from the EPO on substantive principles around validity and infringement even if they do not do so often. In addition to jurisdiction under the EU Biotechnology Directive ${ }^{134}$ the CJEU has assumed exclusive competence on the TRIPS Agreement since 2013. ${ }^{135}$ Internationally and outside of the EPC, or European Union states, the EPO maintains a leading position on patent policy. This can be seen in its association with the Trilateral Office - an entity comprising of USPTO, JPO and the EPO that take common negotiating positions at fora like the World Intellectual Property Office (WIPO). ${ }^{136}$ In general the notion that the EPO is in competition for regulatory space with other state and transnational regulatory agencies within and outside of Europe is a useful dynamic. While the EPO may state that it is in the business of granting patents, ${ }^{137}$ it is really in the business of enforcing the EPC, with its broadly worded statutory provisions and the plurality of interests that represents. It leads us to an important analytical question - in a world where competing values on innovation

\footnotetext{
${ }^{133}$ Brustle v Greenpeace C-34/10.

${ }^{134}$ Directive 98/44/EC on the Legal Protection of Biotechnological Inventions.

${ }^{135}$ Daiichi Sankyo Co. Ltd, Sanofi-Aventis Deutschland GmbH v DEMO Anonimos Viomikhaniki kai Emporiki Etairia Farmakon Case C-414/11.

${ }^{136}$ Louise Davies, 'Technical Cooperation and the International Coordination of Patentability of Biotechnological Inventions’ (2002) 29(1) J of Law and Society 137.

${ }^{137}$ G 1/04 [6], n 76 above.
} 
abound, and attention to compliance ${ }^{138}$ is scare, how does the EPO manage the legitimacy of its legal positions?

Here a constructivist view of legitimacy is particularly useful as it directs attention away from the substantive content of legitimacy debates - such as how to make organisations more democratically legitimate or legitimacy in the sense of justice as well as from the traditional notions of judicial review. It focuses instead on the fluidity and dispersal of influences that we see in the patent regulatory sphere in Europe. It points to the need to explore why EPO positions, riven by textualisation are accepted as legitimate by different stakeholders.

We know the EPO cannot allow patents on computer programs outright (on account of it being excluded) but can grant patents on technical computer implemented inventions where the technicality arises from the internal functioning of a computer. In doing so, it keeps its core constituents - potential patent applicants and key industry players - happy, but also constrains itself within a thinly marked regulatory line on paper by continuing formally to disallow patents on 'computer programs'. Through instrumental use of textualisation, the EPO is able to repair some of the legitimacy lost or revoked by civil society organisations that actively lobby against patents on software. ${ }^{139}$ Similarly and in response to the CJEU's decision in Brustle v Greenpeace, the EPO updated the Guidelines to say that in order to be patentable in Europe, a stem cell invention should not have required the prior destruction of the human embryo at any time in the past, even where such method of

\footnotetext{
${ }^{138}$ Compliance, including under the TRIPS Agreement. Black, Legitimacy and Competition for
} Regulatory Share' n6 above, making the analytical case for using the dynamic of competition for regulatory share by referring to limited attention to compliance.

${ }^{139}$ For instance the Foundation for a Free Information Infrastructure (FFII) and EuroLinux Alliance played vocal roles in coordinating efforts to defeat a proposed EU Directive on Software Patents. 
destruction is not part of the claim. ${ }^{140}$ These revisions adopt the CJEU's position even though the EPO is not formally bound to do so, and in the face of a widely accepted different reading of the EPO's previous stance that focussed only on what was included in the claims. ${ }^{141}$ The particular form of proceduralisation in examination guidelines made possible through textualisation, is instrumental in the optimal management of legitimacy to gain acceptance within a complex network of organisations and values.

\section{$\underline{\text { It sheds functional light on Black's invocation of legitimacy as a sort of }}$} endowment dependent on the acceptance of EPO actions as credible by different stake-holders.

In this context Black's invocation of legitimacy as an endowment,,$\frac{142}{}$ rooted in the acceptance of an organisation by those who are at the receiving end of its actions and that can be revoked, modified or tempered is particularly persuasive in the patent sphere, as the same organisation can be perceived to be less or more successful in problem solving in particular technology sectors. ${ }^{143}$ The legitimacy as endowment

\footnotetext{
${ }^{140}$ EPO Examination Guidelines Part G, Ch II 5.3.
}

${ }^{141}$ Sigrid Sterckx and Julian Cockbain, 'Assessing the Morality of the Commercial Exploitation of Inventions Concerning Uses of Human Embryos and the Relevance of Moral Complicity: Comments on the EPO's WARF Decision,' 2010) 7:1 SCRIPTed 1-241 83-103.

142 n 138 above

${ }^{143}$ For example the EPO is seen as pushing problematic patentability standards that exacerbate the problem of access to medicines and standard essential patents. See n 133 above and EC final report on the public consultation 'Patents and Standards: A Modern Framework for Standardisation Involving Intellectual Property Rights' < http://ec.europa.eu/DocsRoom/documents/4843/attachments/1/translations > accessed 16 September 2016. 
view also allows us to see how legitimacy gained over time may be expended by calling on the credibility that has been historically endowed on the EPO, for instance to push through unusual arrangements such as Swiss use claims.

In so far as legitimacy can be rooted in the acceptance of an organisation, the reasons and circumstances of that acceptance are of paramount importance. ${ }^{144}$ Legitimacy, typically, lies in the shared values, interests, expectations and cognitive frames of those who accept the regime - in this case, the patent community with shared interests that Burk and Reyman and Drahos, amongst others, unpack effectively. ${ }^{145}$ Legitimacy can differ significantly across time and space and between actors, systems and contexts. ${ }^{146}$ Black distils a very useful triptych of relevant reasons for the social acceptance of organisational legitimacy:

Legitimacy may be pragmatically based: the person or social group perceived that an organization will pursue their interests directly or indirectly. It can be morally based: the person or social group perceives the goals and/or procedures of the organization to be morally appropriate. Finally legitimacy can be cognitively based: the organization is accepted as necessary or inevitable. ${ }^{147}$

While none of these reasons need be incompatible with normative legitimacy or indeed even legal validity, different constituents of the patent community may view the legitimacy of the guidelines differently, giving content to the role of legitimacy not as a stable attribute but as a variable endowment. There are those in the patent

\footnotetext{
${ }^{144}$ Black, 'Constructing and Contesting Legitimacy’, n 6 above ,144.

${ }^{145}$ Burk and Reyman, n 53 above; Drahos, n 9 above.

${ }^{146}$ Black, 'Constructing and Contesting Legitimacy’, n 6 above, 145.

147 ibid at 144 citing Lynne G Zuker, 'Institutional Theory of Organisations' (1987) Annual Review of Sociology 13, 443 and Suchman, n 6 above.
} 
community, mostly lawyers and patent agents who represent the interests of their clients pursuing patent rights who would see the guidelines as facilitative of the rights they are in pursuit of. The vision of such constituents of the patent community is necessarily narrow and pragmatic and proportional to the task of applying for a patent based on the invention at hand.

Legitimacy beliefs are also maintained by the community of practitioners who ultimately benefit from the cognitive complexity of the guidelines. To become a purveyor of meaning in the face of complexity is to occupy a rewarding position of authority. Thus it is not unusual to hear a group of patent practitioners agreeing wholeheartedly that many of the specific instances in the Examination Guidelines appear incoherent or against good faith interpretations of the EPC but for pragmatic or cognitive reasons their reflexive attitude will not extend to a rejection of these Guidelines.

Others, for instance the judicial community, may share the pragmatic, and even moral approach to these rules, appropriate to the function they serve. Those who evaluate examination guidelines, typically the growing community of patent activists and commentators, may see them as having cognitive legitimacy - the view that these guidelines are accepted as necessary or inevitable, although the same cognitive basis may also support a critical or exegetic approach to the content and language of such guidelines. Academics who approach the evolution of patent law doctrine critically may find themselves in a bind. An accurate critique of the law necessitates the unpacking of social conventions around guided expectations, but because this is not typically what lawyers analyse it can be surprisingly hard to find critiques that both reflect the significance of examining practice and analytical content of patent law. 
Even law journals may have a hard time publishing such wide ranging content, or attaching credibility to such unusual narratives of how law is made.

Given the complexity of organisational legitimacy, it seem appropriate then not to regard organisations such as patent offices as passive vessels of legitimacy but as active constructors who play a role in their own legitimacy claims some of which are expressed through examining guidelines. While the EPO or the USPTO may have formal monopolies over the subject matter they regulate, there are nonetheless key interactions within and between them and the patent community that makes the construction of legitimacy through modalities like textualisation of primary significance.

Patent offices grow in power by appealing directly to the inventive community for support. ${ }^{148}$ Long describes the USPTO as being on both the demand and supply side in patent law evolution, 'functioning as a demander of some changes to patent policy and as a supplier of others. ${ }^{149}$ Its influence in the market for rules and norms, has even led to it being at odds with other US government agencies. During the CAFC appeal of AMP v Myriad ${ }^{150}$ for instance, the USPTO position in court was directly contradicted by the US Department of Justice ${ }^{151}$ both agencies ostensibly claiming to speak for the US Government.

Most modern patent offices are self-funded by the application and renewal fees paid by the constituents they serve - usually the same constituents who have a stake in easy to obtain patents. Renewal fees in particular influence the decision to

\footnotetext{
${ }^{148}$ Clarissa Long, 'The PTO and the Market for Influence in Patent Law' 157 U. PA. L. REV. 1965.

149 ibid 1966.

${ }^{150}$ Association for Molecular Pathology v USPTO 689 F. 3d 1303.

$151<$ http://patentdocs.typepad.com/files/united-states-amicus-brief-1.pdf $\geq$ accessed 16 September 2016.
} 
patent and are used to finance patent offices. Rather than use patent renewal fees to optimally differentiate between patents and maximize social welfare, ${ }^{152}$ most offices chose uniform patent life which safeguards a valuable source of income ${ }^{153}$ and therefore the power of implementing patent offices.

At the EPO organisationally at least, the principle of 'separation of powers' underpins the structure of the decision-making, and the Boards of Appeal of the EPO are meant to be the independent judicial arm of the European Patent Organisation. In one decision the Enlarged Board depicted the European Patent Organisation as: ....an international, intergovernmental organisation, modelled on a modern state order and based on the separation of powers principle, which the sovereign contracting states have entrusted with the exercise of some of their national powers in the field of patents. ${ }^{154}$

No real system of checks and balances follow from this notional 'separation of powers.' In reality even the judicial independence of the Enlarged Boards have on occasion been thrown in doubt. In one decision the Enlarged Board took on an overly restrictive view of when a point of law requires clarification; based on a reading of Article 112(1)(b) that Pila describes as:

\footnotetext{
${ }^{152}$ Francesca Cornelli and Mark Schankermann, ‘Patent Renewals and R\&D Incentives’ RAND J of Economics Vol 30 no: 2 Summer 1999 97-213. See also Suzanne Scotchmer, 'The Optimality of the Patent Renewal System’ RAND J of Economics Vol 30 no: 2 Summer 1999 181-196.

${ }^{153}$ With respect to the European Patent Organisation, there are reports that it generates year on year an operating budget surplus in the order of hundreds of millions of euros, which is however at odds with the published accounts of the organisation itself. 'A Call for Financial Transparency from the European Patent Office' at <http://ipkitten.blogspot.co.uk/2015/05/a-call-for-financial-transparency-from.html $\geq$ accessed 16 September 2016.
}

${ }^{154} \mathrm{G} 3 / 08$ (n 3 above) at [7.26]. 
...difficult to reconcile with its literal terms, and the 'good faith' interpretation required by Art 31 of the Vienna Convention and that restricts substantially the President's power of referral, thereby increasing the judicial authority of the Technical Boards of Appeal. [footnotes omitted] ${ }^{155}$ In addition to the problems around a distorted conception of 'separation of powers' recently a long-standing labour dispute at the EPO has exposed structural deficiencies which cast further doubt on judicial independence. ${ }^{156}$

Given the charged nature of some of the constituencies that are served by patent offices and diverging views on legitimacy that they might hold, textualisation becomes a key communicative heuristic. Textualised examination guidelines are often presented as products of expertise and their form and substance as necessary, if not inevitable. As Suchman points out construction of legitimacy can take place through conforming, manipulating and informing. ${ }^{157}$ In patent examination guidelines and through the lens of textualisation it is possible to see variations of all three.

\footnotetext{
155 Justine Pila, 'Software Patents, Separation of Powers, And Failed Syllogisms: A Cornucopia from the Enlarged Board of Appeal Of The European Patent Office' (2011) Cambridge Law Journal 70(1) 203-228.

${ }^{156}$ In the words of the Rt Hon Professor Sir Robin Jacob, writing on behalf of the Intellectual Property Judges Association, 'The present events seriously threaten the judicial independence of the Boards of Appeal and by doing that call in question the guarantee of an independent and impartial review of the European Office's decisions by a judicial body. Not tolerating that should be the common interest of all Member States of the European Patent Organisation.' at <http://ipkitten.blogspot.co.uk/2015/01/judicial-independence-europes-ip-judges.html> accessed 16
} September 2016.

${ }^{157}$ Suchman, n 6 above and Paul J DiMaggio and Walter W Powell, 'The Iron Cage Revisited: Institutional Isomorphism and Collective Rationality in Organizational Fields' (April 1983) 48 American Sociological Review 2, 147-160. 
Knowledge and ambiguity in language enable agents to make a choice between alternatives; and therefore change the distribution of power within a system. ${ }^{158}$ Rhetoric or linguistic devices can be used to construct the appearance of knowledge (for example, identifying 'phases' of diagnostic methods) or institutional myths (for example, the idea of notional novelty) in order to provide meaning and increase acceptance amongst the constituents it addresses.

Influential patent offices such as the EPO and the USPTO can also construct legitimacy by joining forces with other patent offices to create in effect peer groups that grant tacit approval to each offices' examination guidelines. The Trilateral Office is a formidable network that conducts joint 'study' exercises on specific technical subject matter including through the scrutiny and acceptance of each other's examining guidelines. These efforts are supported by the difficult-to-surmount expertise barrier that keeps critical theorists and activist commentators at armslength. ${ }^{159}$ Legitimacy may also be enhanced by 'technical assistance' provided to less experienced patent offices. ${ }^{160}$ These can take the form of hardware like computers that are linked to the same technical and knowledge resources used by the more experienced patent offices, or technical 'training' programs or high level 'collaboration' between the examiners of different offices.

In the global patent system, the development of such 'legitimacy networks' is at the heart of the asymmetry in norm-setting power ${ }^{161}$ and the depleted ability of newly established patent offices to formulate rules of practice specific to national

\footnotetext{
${ }^{158}$ Alvesson 'Organizations as Rhetoric', see n 64 above.

${ }^{159}$ Parthasarathy, n 9 above.

${ }^{160}$ Peter Drahos, 'Trust Me’: Patent Offices in Developing Countries 2008 AM J LAW MED vol. 34, (2-3) 151-174.

${ }^{161}$ Chon, n 125 above.
} 
socio-economic conditions. Such networks can inhibit regulatory sovereignty ${ }^{162}$ through largely invisible institutional processes that propel the credibility of claims of legitimacy of examination practices. 'Legitimacy beliefs ${ }^{\text {'163 }}$ such as those around Swiss-type use claims can make it very difficult for those outside of such networks to contest the status quo. For instance when India set out new patent examination guidelines for pharmaceuticals in 2014 it rejected the novelty of product claims based on second medical indication ${ }^{164}$ - the typical Swiss-type use claims - a move that was critically attacked by entities within the legitimacy networks of the patent offices that nurture such claims. ${ }^{165}$ More recently however India's s 3(d) was favourably referred to by the UN Secretary General's High Level Panel on Access to Medicines. ${ }^{166}$

There are at least two further frontlines where textualisation and the institutional processes that facilitate legitimacy claims raise the stakes even higher. First, patent examination guidelines are an important tool in taking advantage of international treaty flexibilities; they are consequently crucial to the de facto

\footnotetext{
${ }^{162}$ See 'Declaration on Patent Protection: Regulatory Sovereignty under TRIPS' at <http://www.mpg.de/8132986/Patent-Declaration.pdf> accessed 16 May 2015.

${ }^{163}$ Black, 'Constructing and Contesting Legitimacy', n 6 above, 147.

${ }^{164}$ n 117 above.

165 The Pharmaceutical Research and Manufacturers of America (PhRMA) (12 August 2014) claimed a 'bias against the pharmaceutical sector' and the International Federation of Pharmaceutical Manufacturer and Associations (IFMPA) stated, 'This exclusion disincentivises innovation related to known products, thereby depriving Indian patients of the fruits of important 'incremental innovation' that results in better therapies and renders India out of step with other jurisdictions'. All comments are responses available at
} <http://ipindia.nic.in/iponew/comments_PharmaGuidelines/FeedBack_Pharmaceuticals.htm $>$ accessed 16 September 2016.

${ }^{166}$ Available at <http://www.unsgaccessmeds.org/final-report/> accessed 16 September 2016. 
harmonisation of trade-related patent rights. The TRIPS Agreement prohibits the making of special standards for specific kinds of subject matter because it has a nondiscrimination provision. Such a clause however does not extend to 'bona fide differentiation, ${ }^{, 167}$ which is a more subtle means of applying legal standards in a technology-specific way. Textualisation is one of the processes through which differentiation can be actualized. While both examples in this paper demonstrate lowered standards of patentability, a newly established patent office in a developing country could also use textualisation to heighten or tailor standards of patentability.

A second new frontline of concern is the European Unified Patent Court, which is expected to begin work sometime in 2017. The EPO is driving the many changes needed to establish and run such a court, including the training of putative judges ${ }^{168}$ which is a startling achievement for an administrative body that is not itself staffed by personnel with judicial qualifications. Other commentators have pointed out how the unitary patent package is 'schizophrenic' 169 (because of the push to remove the court from the EU legal framework) or those orchestrating it are 'the patent microcosm ${ }^{170}$ (referring to the narrow epistemic community that has formed at

\footnotetext{
${ }^{167}$ See n 163 above.

${ }^{168}$ A dedicated training centre for the Unified Patent Court has been established in Budapest (<http://www.epo.org/news-issues/news/2014/20140313.html $\geq$ accessed 16 May 2015) and it is expected that the 'EPO, with its long experience in training patent specialists, will offer its expertise and knowledge to facilitate the creation of a new centralised jurisdiction for patents in Europe.'

169 Thomas Jaeger, 'All Back to Square One? - An Assessment of the Latest Proposals for a Patent and Court for the Internal Market and Possible Alternatives' (2012) International Review of Intellectual Property and Competition Law (IIC) 286.

170 'An Inside View of the Patent Microcosm’ at <http://www.unitary-patent.eu/content/inside-viewpatent-microcosm $\geq$ accessed 16 May 2015.
} 
the European level led by the EPO). It seems likely then that textualisation or a version of it may leak into the judicial culture of the new court. Unburdened by normative principles, textualisation is the lowest common denominator of credible and effective persuasion and given the complex court structure and vastly different legal and judicial cultures, once set may become difficult to shift.

\section{Conclusion}

This paper demonstrates the critical significance of language and rhetoric in the international regulatory space around the protection of inventions. Textualisation is a communicative heuristic that allows contested legal standards to be resolved; and consequently for the credible management of the legitimacy of such outcomes. As an explanatory mechanism it is uniquely appropriate to the patent system because of the dominance of technolaw, and the carefully arranged ambiguity in the legal status of examination guidelines. While textualisation may be value neutral, it is also susceptible to being captured for partisan purposes such as strengthening the protection offered to particular inventions or inveigling allied patent offices to adopt similar measures through legitimacy networks and beliefs. The heuristic potential to manipulate and influence is particularly effective where the regulatory problem itself is fragmented, complex and inter-dependent, as in the case of the regulatory regime that governs the monopolisation of inventions and controls innovation trajectories. This conclusion will lend support to many who see a growing incoherence in European patent law. It also begs the further question, if organisations like the EPO are competing internationally to be seen as legitimate arbiters of innovation policy, how can we make this legal space more effective, fair or purposive, and based on what criteria? 
